\title{
Bacillus Thuringiensis Predominated in the Zombie Fungus Ophiocordyceps Unilateralis S. L.-Infected Ant Cadavers and Investigation of its Biological Properties
}

\section{Kai-Wen Tu}

National Changhua University of Education

Ming-Chung Chiu

National Changhua University of Education

Wei-Jiun Lin

National Changhua University of Education

Yen-Ping Hsueh

Institute of Molecular Biology, Academia Sinica

Chung-Chi Lin

National Changhua University of Education

Jui-Yu Chou ( $\nabla$ jackyjau@cc.ncue.edu.tw)

National Changhua University of Education

\section{Research Article}

Keywords: Bacillus thuringiensis, Ophiocordyceps unilateralis sensu lato, entomopathogenic fungus, bacterial community, saprophyte

Posted Date: July 27th, 2021

DOI: https://doi.org/10.21203/rs.3.rs-690530/v1

License: (c) (i) This work is licensed under a Creative Commons Attribution 4.0 International License. Read Full License 


\section{Abstract}

Animal hosts infected and killed by parasitoid fungi become a nutrient-rich cadaver for saprophytes. Bacteria adapted to colonization of parasitoid fungi can be selected and can predominate in the cadaver, actions that consequently impact the fitness of the parasitoid fungi. In Taiwan, the zombie fungus, Ophiocordyceps unilateralis sensu lato (Clavicipitaceae: Hypocreales), was found to parasitize eight ant species, with preference for a principal host, Polyrhachis moesta. In this study, ant cadavers grew a fungal stroma that was predominated by Bacillus thuringiensis. The bacterial diversity in the principal ant host was found to be lower than the bacterial diversity in alternative hosts, a situation that might enhance the impact of $B$. thuringiensis on the sympatric fungus. The $B$. thuringiensis isolates from fungal stroma displayed higher resistance to a specific naphthoquinone (plumbagin) than $B$. thuringiensis from the environment. Naphthoquinones are known to be produced by 0 . unilateralis $s$. I., and hence the resistance displayed by $B$. thuringiensis isolates to these compounds suggests an advantage to $B$. thuringiensis to grow in the ant cadaver. Bacteria proliferating in the ant cadaver inevitably compete for resources with the fungus. However, the $B$. thuringiensis isolates displayed in vitro capabilities of hemolysis, production of hydrolytic enzymes, and antagonistic effects to co-cultured nematodes and entomopathogenic fungi. Thus, co-infection with $B$. thuringiensis offers potential benefits to the zombie fungus in killing the host under favorable conditions for reproduction, digesting the host tissue, and protecting the cadaver from being taken over by other consumers. With these potential benefits, $B$. thuringiensis is not entirely a competitor but could also be a synergist in 0 . unilateralis $s$. I. infections under certain conditions.

\section{Introduction}

Fungi and bacteria often live in close proximity and share the same microhabitats. The inevitable competition for limited resources promotes the selection of partners tolerant to the presence of each other. Ecological interactions that are either antagonistic or synergistic can develop. Competition for the same resources enhances the antagonistic relationship in many fungus-bacterium associations ${ }^{1}$. However, fungi and bacteria can co-occur synergistically, enhancing the adaptations of each other and consequently forming a co-evolving metaorganism².

The ant-pathogenic fungus, Ophiocordyceps unilateralis sensu lato, is a well-known parasitoid that causes manipulated behaviors and subsequent death of the ant hosts ${ }^{3}$. Spores invade the ant hosts by attaching, germinating, and penetrating the cuticles of foraging ant workers. The fungus lives in a yeastlike state as single cells in the host hemolymph and causes a series of host behavioral manipulations, which is the origin of the name "zombie ant." These include convulsion, erratic walking, and finally, the host dying after biting onto leaf veins or twigs. The fungus produces hyphae to form a branching network of cells throughout the ant cadaver ${ }^{4}$, exploits resources by lysing the host tissue, and ends the parasitic life cycle with a stroma sprouting from the intersegmental membrane between the head and prothorax of the host, forming the perithecial plates for spreading spores ${ }^{5}$. 
During the $~ 1-2$ weeks in which hyphal development occurs in the ant cadaver ${ }^{5}$, the fungus is under selective pressure for host resource exploitation and defense against invaders. Animal cadavers in the terrestrial environment are a nutrient-rich resource for saprophytes ${ }^{6}$. The scarcity of cadavers due to patchy distribution, transient nature, and short supply ${ }^{7}$ promotes rapid colonization and consumption of the available resource by bacteria, which results in a quick succession of microbial populations ${ }^{8}$. However, fungal colonization renders the resource unavailable for most bacteria. Fungal products, such as penicillin ${ }^{9}$, usually result in significantly reduced microbial biodiversity. In the case of $O$. unilateralis $s$. I.-infected ant cadavers, naphthoquinone derivatives are produced by 0 . unilateralis and affect growth of sympatric bacteria negatively ${ }^{10-12}$. Bacterial communities shaped by fungal colonization have been characterized in various environments and the specific impacts on both organisms have been described ${ }^{2}$. However, bacterial communities in insect cadavers colonized by parasitoid fungi have been described less frequently ${ }^{13-14}$.

In the present study, we describe the bacterial community in 0 . unilateralis $s$. I-infected ant cadavers and examine the biological properties of the predominant bacterial species. In Taiwan, 0 . unilateralis s. I. was found to infect eight sympatric species: seven Polyrhachis ant species and Camponotus punctatissimus ${ }^{15}$. Despite not being as highly host specific as its relatives in Brazil, Japan, North America, and Thailand ${ }^{16-19}$, Taiwanese $O$. unilateralis $s$. I. prefer to infect $P$. moesta more than the other seven ant species. With $P$. moesta, Taiwanese $O$. unilateralis $s$. I displays better infection performance, including higher prevalence, developmental rate, and efficiency in host behavior manipulation ${ }^{15}$. Using a culture-dependent method to capture the bacterial community in the principal host, $P$. moesta, and an alternate sympatric host, $P$. wolfi, we found $B$. thuringiensis to be a predominant species in cadavers of both ant species. These bacterial isolations are hypothesized to be more adapted to fungal colonization due to tolerance to naphthoquinones. We investigated this hypothesis by examining resistance to the fungus' antibiotic effect on bacterial growth. Because the predominant bacterial species occupied more than $35 \%$ of the individuals (see results), we further investigated the possible impact on 0 . unilateralis s. I. infection by examining the $B$. thuringiensis isolates for biological properties potentially related to hostkilling (hemolysis and presence of pathogenic and antibiotic genes), resource exploitation (capabilities for lysing host tissue), and defense against possible invaders of the host cadaver (lethal effects on scavenger nematodes and antagonism toward entomopathogenic fungi).

\section{Materials And Methods}

\section{Sample collection}

Samples were collected from an evergreen broadleaf forest in central Taiwan (Lienhuachi Experimental Forest, Nantou County, 23⒌ $5^{\prime} 7^{\prime \prime} \mathrm{N} 120^{\circ} 52^{\prime} 58^{\prime \prime E}$ ) from January 2017 to March 2018; The permission to collect the plants for the study was obtained from the Lianhuachi Research Center, Taiwan Forestry Research Institute, Council of Agriculture, Executive Yuan, Taiwan (Permission no.: 1062272538). The authors confirm that the present study complies with the IUCN Policy Statement on Research Involving 
Species at Risk of Extinction and the Convention on the Trade in Endangered Species of Wild Fauna and Flora. Ant cadavers with fungal growth were collected from the canopy of understory plants with a height of $<3$ meters. Ant cadavers infected by 0 . unilateralis $\mathrm{s}$. I. were carefully removed by cutting the leaf and placing it into a $50 \mathrm{~mL}$ conical centrifuge tube, which was then transported to the laboratory. Only cadavers in which the fungal growth stage preceded the development of perithecia, which theoretically has the highest biological activity, were collected (Fig. 1). In total, 24 infected $P$. moesta and 20 infected $P$. wolfi samples were pooled, respectively, and examined in this study.

\section{Isolation and cultivation of bacteria}

Ants on the leaves were first identified to species, and then each ant was carefully placed using tweezers into a sterilized $1.5 \mathrm{~mL}$ microcentrifuge tube (see details in Lin et al. ${ }^{15}$ ). Samples were vortexed in $600 \mu \mathrm{L}$ sterilized water for a few seconds at 3,000 revolutions/min (rpm) using a vortex mixer (AL-VTX3000L, CAE technology Co., Ltd.), and were then soaked with $600 \mu \mathrm{L} 70 \%$ ethanol to sterilize the ant's surface.

The ethanol on the samples was washed out twice with $600 \mu \mathrm{L}$ of sterilized water, then finally vortexed in $400 \mu \mathrm{L}$ of sterilized water. Next, $200 \mu \mathrm{L}$ of the supernatant was spread homogeneously onto an LB agar plate ( $25 \mathrm{~g}$ Luria-Bertani broth and $15 \mathrm{~g}$ agar per liter) to confirm the absence of live bacteria.

Bacteria from the inside of the ant host were released by homogenizing the ant host in $200 \mu \mathrm{L}$ water and culturing on LB agar plates at $28^{\circ} \mathrm{C}$ for two days. Approximately 45 (43-46) isolates were randomly picked from each plate with sterile toothpicks, and were suspended in the LB medium supplemented with $15 \%$ $\mathrm{v} / \mathrm{v}$ glycerol and maintained at $-80^{\circ} \mathrm{C}$ until the time of examination. In total, 247 bacterial isolates from $P$. moesta and 241 bacterial isolates from $P$. wolfi were collected.

In addition to the bacterial isolates from the ant bodies, 60 bacterial isolates from soil, leaves, and air in the same forest were collected with the same aforementioned procedure, for the purpose of comparing their resistance to naphthoquinones (see below).

\section{Bacterial identification}

Bacteria collected from the ant hosts were identified by gene marker sequencing. The bacterial isolates were cultured in LB medium at $28^{\circ} \mathrm{C}$ overnight to reach the log-phase, and genomic DNA was extracted following the methods described in Vingataramin and $\mathrm{Frost}^{20}$. Conspecies/strain of the bacterial isolates from the same host was determined using the randomly amplified polymorphic DNA (RAPD) method with the primer 5'-GAGGGTGGCGGTTCT-3'. The PCR amplification was performed as follows: initial denaturation at $95^{\circ} \mathrm{C}$ for $5 \mathrm{~min}, 40$ cycles of amplification including denaturation at $95^{\circ} \mathrm{C}$ for $1 \mathrm{~min}$, annealing at $42^{\circ} \mathrm{C}$ for $30 \mathrm{~s}$, and extension at $72^{\circ} \mathrm{C}$ for $1 \mathrm{~min}$, followed by a final extension at $72^{\circ} \mathrm{C}$ for 10 min. PCR products were run in $2 \%$ agarose gel and the bacterial isolates were characterized by the fragment patterns. For each of the ant hosts, bacterial isolates with the same RAPD pattern were considered as the same strain. In total, 106 and 178 strains were found from each of the ant hosts, respectively. One of the bacterial isolates was selected at random to represent the strain and coded with JYC followed by a series of numbers. Taxonomic status of each strain was identified to species by the 
selected isolates and identifying it using the V3/V4 region of the 16S rDNA gene. PCR amplification with the primer set (8F: 5'-AGAGTTTGATCCTGGCTCAG-3' and 1541R: 5'-AAGGAGGTGATCCAGCCGCA-3') 21-22 was performed under the following conditions: initial denaturation at $95^{\circ} \mathrm{C}$ for $5 \mathrm{~min}, 40$ cycles of amplification including denaturation at $95^{\circ} \mathrm{C}$ for $1 \mathrm{~min}$, annealing at $55^{\circ} \mathrm{C}$ for $30 \mathrm{~s}$, and extension at $72^{\circ} \mathrm{C}$ for $1 \mathrm{~min} 45 \mathrm{~s}$, followed by a final extension at $72^{\circ} \mathrm{C}$ for $10 \mathrm{~min}$. The PCR products were first checked by running a gel, and were then sequenced at Genomics, Inc. (New Taipei City, Taiwan). Taxa for the sequences were judged by the BLAST method against nucleotide sequences in the NCBI database (https://www.ncbi.nlm.nih.gov/). Genbank accession numbers of the sequences uploaded to the NCBI database were provided in Supplementary file 1.

The 60 bacterial isolates collected from the environment were examined using the RAPD method and a Bacillus-specific primer set (5'-CTTGCTCCTCTGAAGT TAGCGGCG-3' and 5'-

TGTTCTTCCCTAATAACAGAGTTTTACGACCCG-3'), with the PCR conditions suggested in Nakano et al. ${ }^{23}$. Twenty of the bacterial isolates (10 Bacillus and 10 non-Bacillus) with different RAPD patterns were collected for further experiments.

\section{Bacterial diversity of the two ant host species}

Three biodiversity indexes (Chao1 richness, exponential of Shannon entropy, and inverse Simpson concentration) of bacterial species were estimated by the sample size-based rarefaction/extrapolation sampling curve based on the abundance of bacterial isolates from each of the two ant host species ${ }^{24}$. The calculation was conducted using $\mathrm{R}^{25}$ with the "iNEXT" package ${ }^{26}$.

\section{Biological properties of bacterial isolates from infected ants}

For examining the biological properties of the most predominant species, $B$. thuringiensis (see results), eleven from 47 and ten from 63 of the $B$. thuringiensis strains from $P$. moesta and $P$. wolfi, respectively, were selected. The strains were selected according to the UPGMA analysis of the sequence. One to three strains grouped in the same cluster were selected (Fig. S1). In addition, six from 15 strains of the second predominant Bacillus species (B. gibsonii) in $P$. wolfi, as it occupied approximately $20 \%$ of the individuals among Bacillus, were also randomly selected for the examinations.

All the selected strains were used to examined the biological properties including potential 1) capability of the isolate to lyse host tissue (hydrolytic enzymes); 2) defense against fungal competition for the ant cadaver, presence of pathogenic and antibiotic genes; and 3) resistance to naphthoquinone derivatives. In addition to the repellence against entomopathogenic fungi, one of the $B$. thuringiensis strains from each of the hosts was selected at random for examining the potential impact on the nematode invasion.

Hemolysis reaction

Hemolysis reaction tests were conducted on tryptic soy agar (TSA) plates (15 g pancreatic digest of casein, $5 \mathrm{~g}$ soybean meal, $5 \mathrm{~g} \mathrm{NaCl}$, and $15 \mathrm{~g}$ agar, with final $\mathrm{pH}$ of 7.3) mixed with $5 \%$ defibrinated sheep 
blood, which was added to the TSA after it had cooled down to approximately $50^{\circ} \mathrm{C}$. One $3 \mu \mathrm{L}$ drop of the log-phase bacterial suspension was placed onto each TSA plate and incubated at $28^{\circ} \mathrm{C}$ for $1-2$ days.

The hemolysis reaction was determined by the formation of clean ( $\beta$-hemolysis) or greenish ( $a-$ hemolysis) hemolytic zones, or no such zone ( $\gamma$-hemolysis, non-hemolytic) around the bacterial colonies $^{27}$.

\section{Production of hydrolytic enzymes}

The production of hydrolytic enzymes was examined by culturing a $3 \mu \mathrm{L}$ drop of the exponential-phase bacterial suspension on four different types of plated media: chitinase detection medium (solid medium with $0.3 \mathrm{~g} \mathrm{MgSO}_{4} .7 \mathrm{H}_{2} \mathrm{O}, 3 \mathrm{~g}\left(\mathrm{NH}_{4}\right)_{2} \mathrm{SO}_{4}, 2 \mathrm{~g} \mathrm{KH}_{2} \mathrm{PO}_{4}, 1 \mathrm{~g}$ citric acid monohydrate, $0.15 \mathrm{~g}$ bromocresol purple, $200 \mu \mathrm{L}$ Tween $80,4.5 \mathrm{~g}$ colloidal chitin, and $1 \mathrm{~L}$ deionized water with $1.5 \%[\mathrm{w} / \mathrm{v}]$ agar and final $\mathrm{pH}$ of 4.7); skim milk agar (solid medium with $2 \%$ [w/v] agar, $28 \mathrm{~g}$ skim milk powder, $5 \mathrm{~g}$ casein enzymic hydrolysate (Tryptone), $2.5 \mathrm{~g}$ yeast extract, $1 \mathrm{~g}$ dextrose, and $1 \mathrm{~L}$ deionized water); lipase agar (solid medium with $2 \%[\mathrm{w} / \mathrm{v}]$ agar, $0.1 \mathrm{~g}$ phenol red, $1 \mathrm{~g} \mathrm{CaCl}_{2}, 10 \mathrm{~mL}$ olive oil, and $1 \mathrm{~L}$ deionized water, with final $\mathrm{pH}$ of 7.4); and esterase agar (solid medium with $2 \%\left[\mathrm{w} / \mathrm{v}\right.$ ] agar, $0.1 \mathrm{~g}$ phenol red, $1 \mathrm{~g} \mathrm{CaCl}_{2}, 10 \mathrm{~mL}$ tributyrin, and $1 \mathrm{~L}$ deionized water, with final $\mathrm{pH}$ of 7.4). The chitinase detection medium was used to examine purple zones, indicating chitinase activity ${ }^{28-29}$; the skim milk agar medium was used to examine clearance zones for proteases activity ${ }^{30}$; and the lipase and esterase agar media were used to examine yellow zones, indicating lipase and esterase activity, respectively ${ }^{31}$.

\section{Pathogenic and antibiotic genes}

The total genomic DNA of Bacillus strains was extracted by using an AccuPrep genomic DNA extraction kit (Bioneer) for PCR amplification. The specific screening primers for amplifying the genes, including $c r y$, cyt, Iturin, Chitinase, Bacillomycin, Fengycin, Surfactin, vip, and Zwittermicin A, were used under PCR conditions suggested in previous studies ${ }^{32-35}$. The primer sets used for the amplifications are listed in Table S2-1.

Lethal effects on Caenorhabditis elegans

Antagonistic effects of $B$. thuringiensis isolates on the model nematode, Caenorhabditis elegans, were examined by estimating the potential of hemolytic $B$. thuringiensis to prevent competition by scavengers for the resource-rich insect cadavers ${ }^{36}$. Daily mortality of $C$. elegans strain N2 was examined in response to one random selected $B$. thuringiensis strain ( $B$. thuringiensis JYCB227 from $P$. moesta and $B$. thuringiensis JYCB302 from $P$. wolfi) in comparing with one strain of the second predominated Bacillus species (B. drentensis JYCB252 from P. moesta and B. gibsonii JYCB395 from P. wolfi).

Synchronized L4 nematodes were grown on nematode growth medium (NGM; $3 \mathrm{~g} \mathrm{NaCl}, 2.5 \mathrm{~g}$ peptone, 17 g agar, $5 \mathrm{mg}$ cholesterol, $1 \mathrm{~mL} 1 \mathrm{M} \mathrm{CaCl}_{2}, 1 \mathrm{~mL} 1 \mathrm{M} \mathrm{MgSO}_{4}, 25 \mathrm{~mL} 1 \mathrm{M} \mathrm{KH}_{2} \mathrm{PO}_{4}$, and $\mathrm{H}_{2} \mathrm{O}$ to 1 liter) agar plates seeded with Escherichia coli OP50. The Bacillus isolates were prepared by inoculating in $3 \mathrm{~mL} \mathrm{LB}$ 
liquid broth at $20^{\circ} \mathrm{C}$ overnight, and then adjusting to an absorbance of optical density (O.D.) 0.2 at a wavelength of $600 \mathrm{~nm}$.

To test the survival rate of $C$. elegans in the presence of various bacteria, L4 nematodes were co-cultured with 1) a hemolytic bacterial strain, 2) a non-hemolytic bacterial strain, 3) a hemolytic strain $+E$. coli OP50, 4) a non-hemolytic strain + E. coli OP50, and 5) E. coli OP50 only (control). Twenty $\mu \mathrm{L}$ of bacterial culture was added to a $35 \mathrm{~mm}$ NGM agar plate and spread evenly with a glass rod. For each treatment, 30 L4 larvae were cultured on the NGM agar plate and their survival was monitored daily for seven days. Each treatment was replicated three times.

Survival curves were compared using a survival analysis with treatment as the fixed effect. The significance of fixed effect was assessed by model reduction and the likelihood ratio test. Post hoc multiple comparisons were conducted with Tukey's all-pair comparisons. The model building and hypothesis tests were conducted by using the"survival" and "multcomp" packages in R.

\section{Antagonism to entomopathogenic fungi}

We examined the response of three entomopathogenic fungi, including Aspergillus nomius (isolated from the ant Dolichoderus thoracicus), Trichoderma asperellum (isolated from the litchi stink bug, Tessaratoma papillosa), and Purpureocillium lilacinum (isolated from T. papillosa), to co-cultured Bacillus strains. The entomopathogenic fungi were prepared by culturing on potato dextrose agar (PDA) plates for 4 (A. nomius, $T$. asperellum) or 10 (P. lilacinum) days at $28^{\circ} \mathrm{C}$, until the mycelia covered approximately $80 \%$ of the plate.

A piece of mycelium (approximately $5 \times 5 \mathrm{~mm}^{2}$ ) was seeded in the center of a TSA plate and surrounded by three equidistant $3 \mu \mathrm{L}$ drops of exponential-phase bacterial suspension. Plates were incubated at $20^{\circ} \mathrm{C}$ for 7-10 days. After incubation, areas of the mycelium occupying the plate surface were photographed and measured using Image $\mathrm{J}$. Each pair of bacteria and entomopathogenic fungi, plus the control (a piece of mycelium not surrounded by the bacterial suspension) was replicated 3-4 times.

Antagonism was estimated based on the percentage of mycelial growth inhibition (MGI), which was calculated using the formula $\left(\left[R_{c}-R_{\text {exp }}\right] / R_{c}\right) \times 100 \%$, where $R_{c}$ is the mean area of the control fungus and $R_{\exp }$ is the mean area of the examined entomopathogenic fungus co-cultured with each of the Bacillus strains ${ }^{37}$. The MGI values among all entomopathogenic fungi were compared using a beta regression model with the Bacillus species as the fixed effect. The significance of the Bacillus species effect was tested by comparing the full model with a model that removed the fixed effect term by using a likelihood ratio test. Post hoc tests were conducted using a Tukey-adjusted pairwise comparison. The statistical analysis was conducted using the R packages "betareg," "emmeans," "Imtest," and "multcomp." 
To examine the resistance of bacterial isolates to naphthoquinones, the growth of 11 predominant $B$. thuringiensis strains isolated from the principal ant host was compared with the growth of 20 environmental bacterial isolates (10 Bacillus and 10 non-Bacillus) using two naphthoquinones, respectively. The two naphthoquinones prepared for the experiment, plumbagin ${ }^{38}$ and lapachol ${ }^{39}$, were dissolved in $30 \%$ dimethyl sulfoxide (DMSO) water solution ${ }^{38}$. Naphthoquinone concentrations were determined from the serial dilutions in which three randomly selected bacteria from the ant host and three from the environment had the most distinctive growth rate. Based on these results, concentrations of 45 $\mu \mathrm{g} / \mathrm{mL}$ (plumbagin) and $64.5 \mu \mathrm{g} / \mathrm{mL}$ (lapachol) were used (Fig. S2).

In this experiment, the bacterial isolates were first inoculated in LB medium at $20^{\circ} \mathrm{C}$ overnight and were then refreshed to the exponential phase with LB medium for 3 hours. The bacterial concentration was adjusted to $\sim 1.5 \times 10^{8}$ cells $/ \mathrm{mL}$. Next, $10 \mu \mathrm{L}$ of the bacterial suspension and $180 \mu \mathrm{L}$ Mueller Hinton broth medium (Sigma-Aldrich) were added to either $10 \mu \mathrm{L}$ naphthoquinone solution or $10 \mu \mathrm{L} 30 \%$ DMSO water solution for the control. The growth of bacterial isolates at $20^{\circ} \mathrm{C}$ was monitored by measuring the O.D. value at $600 \mathrm{~nm}$ with a Multiskan GO microplate spectrophotometer (Thermo Scientific) every hour for 12 hrs. Each combination of bacterial isolate and naphthoquinone or control was replicated twice. Four bacterial isolates (one $B$. thuringiensis from the ant host, plus two Bacillus and one non-Bacillus from the environment) were omitted from the analysis due to low growth rate in the media with DMSO (O.D. value lower than 0.05 at the end of $12 \mathrm{hr}$ ).

The resistance index of each bacterial isolate was calculated by the normalized difference of the O.D. value in the naphthoquinone-treated medium versus the control medium ([naphthoquinone DMSO]/[naphthoquinone + DMSO]). Values closer to 1 represent higher resistance to the presence of naphthoquinone. Resistance index was compared among the bacterial isolates from different resources (B. thuringiensis from the ant host, Bacillus from the environment, and non-Bacillus from the environment) using a linear mixed model with resource as the fixed effect, bacterial isolate as a random effect, and growth time (5-12 hrs) as a nest effect. The significance of resource as a fixed effect was assessed by model reduction and the likelihood ratio test. Post hoc multiple comparisons were made using Tukey's all-pair comparisons. The model building and hypothesis tests were conducted using the "Ime4" and "multcomp" packages in R.

\section{Results}

\section{Relative abundance and diversity of cultivated bacteria in infected ant hosts}

A total of 247 and 241 bacterial isolates were obtained from infected $P$. moesta and $P$. wolfi, respectively. Firmicutes predominated in both of the infected ant species (95.55\% in $P$. moesta and $87.14 \%$ in $P$. wolfi), followed by Actinobacteria (4.05\% in P. moesta and $12.86 \%$ in $P$. wolfi) and Proteobacteria $(0.40 \%$ in $P$. moesta and $0 \%$ in $P$. wolfi). At the genus level, Firmicutes were composed of Bacillus 
(61.54\%), Staphylococcus (26.32\%), Paenibacillus (4.86\%), Lysinibacillus (2.43\%), Terribacillus (0.40\%), and Streptomyces (0.40\%) in the infected P. moesta, and Bacillus (71.78\%), Paenibacillus (4.56\%), Oceanobacillus (3.73\%), Lysinibacillus (2.90\%), Sporosarcina (2.07\%), Staphylococcus $(1.24 \%)$, Rummeliibacillus (0.41\%), and Virgibacillus $(0.41 \%)$ in the infected $P$. wolfi. Actinobacteria were composed of Gordonia (3.24\%) and Tsukamurella (0.40\%) in the infected P. moesta, and Kocuria (7.05\%), Brachybacterium (3.73\%), Dermacoccus ( $0.83 \%)$, Kytococcus $(0.83 \%)$, and Micrococcus $(0.41 \%)$ in the infected $P$. wolfi. The sole genus belonging to Proteobacteria was Brevundimonas $(0.40 \%)$ in the infected $P$. moesta (Fig. 2; Table S1). The genus Bacillus also contained the most predominant species, $B$. thuringiensis, in both of the hosts (44.94\% in $P$. moesta and $36.93 \%$ in $P$. wolfi).

The number of bacterial species detected in infected $P$. wolfi (38 species, estimated sample coverage: $94.21 \%$ ) was more than that in infected $P$. moesta (27 species, estimated sample coverage: $95.97 \%$ ). Sample size-based rarefaction and extrapolation curves also showed a higher diversity of microbiota in infected $P$. wolfi in all three biodiversity indexes. Figure 2 (S3) suggests an overall increased diversity of host-associated bacterial communities in infected $P$. moesta compared with $P$. wolfi.

\section{Hemolytic activity of bacterial isolates}

In the 247 and 241 bacterial isolates from $P$. moesta and $P$. wolfi, respectively, $117(47.37 \%)$ and 110 (45.64\%) of them displayed the $\beta$-hemolysis reaction. At the species level, 7 of 27 (25.93\%) bacterial species from $P$. moesta and 11 of $38(28.95 \%)$ from $P$. wolfi had at least one isolate display the $\beta$ hemolysis reaction. Bacterial isolates belonging to four of the nine genera from $P$. moesta displayed hemolytic activity. Among those, $83.33 \%$ of the isolates were Lysinibacillus, $72.37 \%$ were Bacillus, $8.33 \%$ were Paenibacillus, and $1.54 \%$ were Staphylococcus. Among the bacterial isolates from $P$. wolfi, three of the 13 genera displayed hemolytic activity. Among those, $61.85 \%$ of the isolates were Bacillus, $18.18 \%$ were Paenibacillus, and $14.29 \%$ were Lysinibacillus. Within Bacillus, three of 14 species from $P$. moesta and eight of 17 species from $P$. wolfi displayed hemolytic activity (Table S1). None of the isolates showed an a-hemolysis reaction.

\section{Production of hydrolytic enzymes by Bacillus thuringiensis and B. gibsonii}

Among the four hydrolytic enzymes, $B$. thuringiensis isolates from both of the ant hosts displayed protease, lipase, and esterase activities. Chitinase activity was detected in $B$. thuringiensis isolates from $P$. wolfi, but could not be confirmed in the $B$. thuringiensis isolates from $P$. moesta because none of these isolates grew on the chitinase detection medium. Lipase activity was detected in all of the B. gibsonii isolates, but none of the isolates grew on either the chitinase detection medium, skim milk agar (for protease activity), or esterase agar plates (Table S3).

\section{PCR-based screening of endotoxin-related and biosynthetic genes}

Most of the pathogenic and antibiotic genes examined in the current study were not commonly detected in the 11 B. thuringiensis strains from P. moesta, 10 B. thuringiensis strains from $P$. wolfi, or six B. gibsonii 
strains from $P$. wolfi. In the examination of $c r y$ genes, one $B$. gibsonii strain displayed the signal for the cry2 gene, and two $B$. thuringiensis strains from $P$. moesta displayed the signal for the cry 3 gene. The chitinase gene signal was displayed in four $B$. thuringiensis strains from $P$. moesta, two $B$. thuringiensis strains from $P$. wolfi, and one $B$. gibsonii strain. The Surfactin gene signal was displayed in four $B$. thuringiensis strains from $P$. moesta. The Zwittermicin A gene signal was displayed in one $B$. thuringiensis strain from $P$. moesta. The other five genes examined (cyt, Iturin, Bacillomycin, Fengycin, and vip) were not detected in any of the Bacillus strains (Table S2-2, S2-3).

\section{Potential impact of $B$. thuringiensis on Caenorhabditis elegans fitness}

Hemolytic $B$. thuringiensis from both of the ant hosts displayed higher mortality to nematodes than did the coexisting non-hemolytic Bacillus, whereas nematode survival in the presence of non-hemolytic Bacillus was similar to that of the E. coli OP50 control (P. moesta: $X^{2}=80.14$, d.f. $=4, P<0.001$, Fig. 3a; $P$. wolfi: $X^{2}=46.39$, d.f. $=4, P<0.001$, Fig. 3b). The addition of E. coli OP50 slightly increased the survival rate of nematodes co-cultured with hemolytic $B$. thuringiensis isolated from $P$. wolfi (Fig. 3b), but this impact was not seen when using hemolytic isolates from $P$. moesta (Fig. 3a).

\section{Growth inhibition of entomopathogenic fungi by Bacillus isolates}

All three entomopathogenic fungi displayed growth inhibition when they were co-cultured with $B$. thuringiensis from either host species, or with B. gibsonii (A. nomius: $X^{2}=87.21$, d.f. $=2, P<0.001 ; T$. asperellum: $X^{2}=51.06$, d.f. $=2, P<0.001$; P. lilacinum: $X^{2}=76.33$, d.f. $=2, P<0.001$ ). The $B$. thuringiensis from each of the ant hosts displayed similar growth inhibition of the entomopathogenic fungi, whereas $B$. gibsonii had significantly lower growth inhibition (Fig. 4).

\section{Resistance of Bacillus thuringiensis to naphthoquinones}

The bacteria we examined responded differently to the two naphthoquinones used in this study. Bacterial isolates of all three categories ( $B$. thuringiensis from the ant hosts, Bacillus from the environment, and non-Bacillus from the environment) displayed similar resistance to lapachol $\left(X^{2}=1.87\right.$, d.f. $=2, P=0.392$, Fig. 5a), growing similarly to bacteria cultured in the control medium (resistance indexes close to 1 ). In contrast, bacteria isolated from the environment, particularly the Bacillus, grew much slower in the presence of plumbagin than in the control medium, whereas $B$. thuringiensis from the ant host displayed a higher resistance to plumbagin $\left(X^{2}=6.91\right.$, d.f. $=2, P=0.0316$, Fig. $\left.5 b\right)$.

\section{Discussion}

We found that $B$. thuringiensis, which occupied more than $35 \%$ of the total bacterial counts, predominated the bacterial community in 0 . unilateralis s. I.-infected ant cadavers. In a study of the closely related fungus, $O$. sinensis, the Ophiocordyceps-associated microbiomes improved the development and formation of fungal metabolites ${ }^{13-14}$. However, the main bacterial taxa found in the $O$. sinensis-infected host cadavers was not Bacillus ${ }^{13-14}$. In the present study, the proliferation of Bacillus in 
ant cadavers could be from an invasion of the naphthoquinone-resistant population from soil. The genus Bacillus is one of the main bacterial groups in soil ${ }^{40}$. Furthermore, the predominant $B$. thuringiensis from ant cadavers displayed higher resistance to a specific naphthoquinone (plumbagin) than the bacteria isolated from the surrounding environment. Although such differences in the naphthoquinone effect have not been seen in lapachol, unequal antimicrobial activity has been found in previous studies (e.g. $\left.{ }^{41}\right)$. In addition, the $B$. thuringiensis isolates from ant cadavers displayed hydrolytic enzyme activity, which suggests the potential to exploit resources of ant cadavers. Not surprisingly, lower bacterial diversity resulted in a higher abundance of $B$. thuringiensis in cadavers of the principal host, $P$. moesta, in comparison with the alternate sympatric host, $P$. wolfi. The accumulation of naphthoquinones might open a niche for $B$. thuringiensis isolates to out compete other saprophytes, but the lower bacterial diversity in the principal host suggests a more sophisticated manipulation of the physiological conditions of the principal host. Despite not diverging among its sympatric hosts, $O$. unilateralis $\mathrm{s}$. I. displays higher infection performances in one ant species than in the other host species in Taiwan ${ }^{15}$. The efficient exploitation of host resources may result from better modification of host physiological conditions, which consequently causes a more uniform environment for specific bacterial species. Fungi are known to modify the environment for their own benefit ${ }^{2}$. Some of the biological properties of the $B$. thuringiensis isolates, including in vitro hemolysis and antagonistic effects on co-cultured entomopathogenic fungi and nematodes, suggest the potential of a synergistic relationship with 0 . unilateralis $s$. I. However, because artificial infection of the ant host with 0 . unilateralis $s$. I. is difficult under our current laboratory conditions, to date we can only hypothesize about the potential of synergistic effects of $B$. thuringiensis on 0 . unilateralis s. I. infections.

The $B$. thuringiensis isolates from both principal and alternate sympatric hosts are broadly aggressive to potential saprophytic invaders, including fungi and nematodes. One possible factor is their hemolytic ability ${ }^{42-43}$. In comparison with non-hemolytic Bacillus, hemolytic $B$. thuringiensis isolates displayed higher fatal effects to free-living nematodes and growth inhibition of co-cultured entomopathogenic fungi. Collaborative bacteria have been known to assist parasites in occupying the host body by excluding potential invaders, such as nematode scavengers or insect predators ${ }^{36,44-45}$. For these collaborative bacteria, some of the antibiotic activity against invaders may be moderated by the need to compete with invaders for the necessary nutrition ${ }^{46}$, while not obviously affecting the host's survival ${ }^{47}$. In contrast, for the $B$. thuringiensis isolates, in which the host survival is no more a concern, the antibiotic activity could be more intensive and efficient. The $B$. thuringiensis isolates might play a role resembling that of the symbiotic bacteria, Xenorhabdus and Photorhabdus, in entomopathogenic nematodes. Invasion of the insect host by the nematode rapidly causes the insect's death, and septicemia occurs with the proliferation of symbiotic bacteria. The nematodes then colonize the insect cadaver with the symbiotic bacteria, which now serve as "body guards" to defend against invasion by saprophytic or parasitic organisms ${ }^{45}$. Like the $B$. thuringiensis isolates, hemolysis is also detected in $X$. nematophila and likely plays a critical role in killing and preserving the insect host ${ }^{48}$. The outbreak of hemolytic $B$. thuringiensis isolates can be lethal to the ant host, and might explain the lack of endotoxin-related and 
biosynthetic genes due to overlapping functions. Another explanation for the lack of endotoxin-related genes is that the proliferation of $B$. thuringiensis occurs after the host death. However, the precise timing of the outbreak is currently unknown.

Regardless of the timing of $B$. thuringiensis proliferation, $B$. thuringiensis is potentially beneficial to $O$. unilateralis s. I. in protecting and consuming the host cadaver. Bacillus species produce several extracellular enzymes ${ }^{49-50}$, including alkaline proteases, which have been used commercially ${ }^{51}$. The ant cadaver contains nutritious and protein-rich niches for microbiota, but these are only made available in the presence of proteolytic enzymes, which digest the macromolecular proteins into smaller peptides and free amino acids ${ }^{52}$. The proteases activity detected in all of the examined $B$. thuringiensis isolates suggests that symbiotic bacteria are advantageous to 0 . unilateralis $s$. I. in digesting the host tissue. In addition to improving consumption of the host, proteases are important for host epidermal decomposition and enhanced virulence to assist 0 . unilateralis $s$. I. in causing host death ${ }^{53-54}$. Chitin is another major component of insects that functions as a scaffolding material ${ }^{55}$. In addition to releasing nutrients, digesting chitin can be also fatal to the insect host and its invaders. Chitin is a necessary component of the peritrophic matrix secreted by the entire midgut in most insects, and it functions as a protective barrier against abrasive particles and microbial infections ${ }^{56}$. Chitinase secreted by bacteria weakens the insect's peritrophic membrane, and consequently promotes the penetration of bacterial toxins to the gut epithelia during pathogenesis ${ }^{57-58}$. Chitinase produced by bacteria has also been found to present antagonistic activity against fungi, given that chitin is a primary component of fungal cell walls ${ }^{59}$. Digestion of lipids, in contrast to proteases and chitinase, might be less harmful for the living ant because lipids function mainly as storage structures. Nevertheless, lipids are a concentrated source of energy and primary nutrient reserves for fungal spores ${ }^{60}$. Extracellular lipid digestion by $B$. thuringiensis suggests that this bacterium efficiently harvests the energy from the ant cadaver and can symbiotically benefit $O$. unilateralis $s$. I. The hydrolytic enzymes, secreted to the microenvironment, could serve as public goods and enhance the utilization of host resources. The importance of $B$. thuringiensis in consuming the host might be further supported by phylogenetic analysis of enzyme sequences. Unlike the genes for producing secondary metabolites, genes for producing hydrolytic enzymes in 0 . unilateralis s. I. display lower species specificity, which suggests a lack of positive selection among host species ${ }^{61}$. Sharing of the task by sympatric microorganisms reduces the indispensability and selective pressure on fungal hydrolytic enzymes.

The biological properties associated with an outbreak of $B$. thuringiensis suggest potential benefits to $O$. unilateralis s. I. However, the proliferation of $B$. thuringiensis appears coincidental rather than the result of long-term coevolution. In addition, the net effect of the inevitable competition with $B$. thuringiensis for limited resources may prove to be antagonistic rather than synergistic. Co-occurrence of fungi and bacteria can promote the growth of both entities ${ }^{62}$, but it can also accelerate the depletion of resources. Tradeoffs have been reported in fungi between growth and tolerance toward bacteria ${ }^{1}$. In this study, we demonstrated the predominance of $B$. thuringiensis in the bacterial community associated with ant cadavers infected by 0 . unilateralis $\mathrm{s}$. I. These bacterial isolates displayed the capabilities of hemolysis, 
production of hydrolytic enzymes, antagonistic effects to co-cultured nematodes and entomopathogenic fungi, and higher tolerance toward naphthoquinone. At present we still do not have an evidence to conclude the outbreak of $B$. thuringiensis is antagonistic or synergistic toward $O$. unilateralis s. I. However, study of sympatric bacteria will improve our understanding of the parasitic life history and potential selective pressures in $O$. unilateralis $s$. I. In addition, the antibiotic activity of $B$. thuringiensis isolates has potential as a biocontrol agent. With antagonistic effects on entomopathogenic fungi and nematodes, $B$. thuringiensis also has potential agricultural applications in controlling pathogenic fungi ${ }^{63}$ and root-knot nematodes ${ }^{64}$. Through behavioral manipulation of the 0 . unilateralis s. I.- ant parasitic association, the bacterial diversity revealed in this study is a step forward in understanding the impact of microbial communities in parasitic life cycles.

\section{Declarations}

\section{Acknowledgments}

We thank Prof. Wen-Jer Wu (National Taiwan University, Taiwan), and members of the Chou and Lin labs for their helpful discussion and comments on the manuscript. This manuscript was edited by wordvice.com.tw. This work was supported by grants from the Ministry of Science and Technology, Taiwan (MOST 109-2811-B-018-500 and MOST 110-2811-B-018-001 to Ming-Chung Chiu; MOST 1052311-B-018 -001 -MY3 and MOST 108-2621-B-018-002-MY3 to J.-Y. Chou). We are grateful to the Lianhuachi Research Center, Taiwan Forestry Research Institute, Council of Agriculture, Executive Yuan, Taiwan, for its support.

\section{References}

1. Mille-Lindblom, C., Fischer, H. \& Tranvik, L. J. Antagonism between bacteria and fungi: substrate competition and a possible tradeoff between fungal growth and tolerance towards bacteria. Oikos 113, 233-242. https://doi.org/10.1111/j.2006.0030-1299.14337.x (2006)

2. Bosch, T. C. G. \& McFall-Ngai, M. J. Metaorganisms as the new frontier. Zoology 114, 185-190. https://doi.org/10.1016/j.zool.2011.04.001 (2011)

3. de Bekker C. et al. Species-specific ant brain manipulation by a specialized fungal parasite. $B M C$ Evol. Biol. 14, 166. https://doi.org/10.1186/s12862-014-0166-3 (2014)

4. Fredericksen, M. A. et al. Three-dimensional visualization and a deep-learning model reveal complex fungal parasite networks in behaviorally manipulated ants. Proc. Natl. Acad. Sci. USA 114, $12590-$ 12595. https://doi.org/10.1073/pnas.1711673114 (2017)

5. Andersen, S. B. et al. The life of a dead ant: the expression of an adaptive extended phenotype. Am. Nat. 174, 424-433. https://doi.org/10.1086/603640 (2009)

6. Procopio, N. et al. Soil fungal communities investigated by metabarcoding within simulated forensic burial contexts. Front. Microbiol. 11, 1686. https://doi.org/10.3389/fmicb.2020.01686 (2020) 
7. Peschke, K., Krapf, D. \& Fuldner, D. Ecological separation, functional relationships, and limiting resources in a carrion insect community. Zool. Jb. Syst. 114, 241-265. (1987)

8. Dangerfield, C. R., Frehner, E. H., Buechley, E. R., Şekercioğlu, Ç. H. \& Brazelton, W. J. Succession of bacterial communities on carrion is independent of vertebrate scavengers. PeerJ 8, e9307. https://doi.org/10.7717/peerj.9307 (2020)

9. Drews, J. Drug discovery: a historical perspective. Science 287, 1960-1964. https://doi.org/10.1126/science.287.5460.1960 (2000)

10. Amnuaykanjanasin, A., Panchanawaporn, S., Chutrakul, C. \& Tanticharoen, M. Genes differentially expressed under naphthoquinone-producing conditions in the entomopathogenic fungus Ophiocordyceps unilateralis. Can. J. Microbiol. 57, 680-692. https://doi.org/10.1139/w11-043 (2011)

11. Amnuaykanjanasin, A., Phonghanpot, S., Sengpanich, N., Cheevadhanarak, S. \& Tanticharoen, M. Insect-specific polyketide synthases (PKSs), potential PKS-nonribosomal peptide synthetase hybrids, and novel PKS clades in tropical fungi. Appl. Environ. Microbiol. 75, 3721-3732.

https://doi.org/10.1128/AEM.02744-08 (2009)

12. Wichadakul, D. et al. Insights from the genome of Ophiocordyceps polyrhachis-furcata to pathogenicity and host specificity in insect fungi. BMC Genomics 16, 881. https://doi.org/10.1186/s12864-015-2101-4 (2015)

13. Xia, F., Liu, Y., Shen, G. R., Guo, L. X. \& Zhou, X. W. Investigation and analysis of microbiological communities in natural Ophiocordyceps sinensis. Can. J. Microbiol. 61, 104-111. https://doi.org/10.1139/cjm-2014-0610 (2015)

14. Xia, F., Zhou, X., Liu,Y., Li, Y., Bai, X. \& Zhou, X. Composition and predictive functional analysis of bacterial communities inhabiting Chinese Cordyceps insight into conserved core microbiome. $B M C$ Microbiol. 19, 105. https://doi.org/10.1186/s12866-019-1472-0 (2019)

15. Lin, W. J. et al. Evaluating the tradeoffs of a generalist parasitoid fungus, Ophiocordyceps unilateralis, on different sympatric ant hosts. Sci. Rep. 10, 6428. https://doi.org/10.1038/s41598020-63400-1 (2020)

16. Luangsa-Ard,. J J., Ridkaew, R., Tasanathai, K., Thanakitpipattana, D., Hywel-Jones, N. Ophiocordyceps halabalaensis: a new species of Ophiocordyceps pathogenic to Camponotus gigas in Hala Bala Wildlife Sanctuary, Southern Thailand. Fungal. Biol. 115, 608-614. https://doi.org/10.1016/j.funbio.2011.03.002 (2011)

17. Kobmoo, N., Mongkolsamrit, S., Tasanathai, K., Thanakitpipattana, D. \& Luangsa-Ard, J. J. Molecular phylogenies reveal host-specific divergence of Ophiocordyceps unilateralis sensu lato following its host ants. Mol. Ecol. 21, 3022-3031. https://doi.org/10.1111/j.1365-294X.2012.05574.x (2012)

18. Araújo, J. P. M., Evans, H. C., Geiser, D. M., Mackay, W. P. \& Hughes, D. P. Unravelling the diversity behind the Ophiocordyceps unilateralis (Ophiocordycipitaceae) complex: Three new species of zombie-ant fungi from the Brazilian Amazon. Phytotaxa 220, 224-238.

https://doi.org/10.11646/phytotaxa.220.3.2 (2015) 
19. Araújo, J. P. M., Evans, H. C., Kepler, R. and Hughes, D. P. Zombie-ant fungi across continents: 15 new species and new combinations within Ophiocordyceps. I. Myrmecophilous hirsutelloid species. Stud. Mycol. 90, 119-160. https://doi.org/10.1016/j.simyco.2017.12.002 (2018)

20. Vingataramin, L. \& Frost, E. H. A single protocol for extraction of gDNA from bacteria and yeast. Biotechniques 58, 120-125. https://doi.org/10.2144/000114263 (2015)

21. Edwards, U., Rogall, T., Blocker, H., Emde, M. \& Bottger, E. C. Isolation and direct complete nucleotide determination of entire genes. Characterization of a gene coding for $16 \mathrm{~S}$ ribosomal RNA. Nucleic. Acids Res. 17, 7843-7853. https://doi.org/10.1093/nar/17.19.7843 (1989)

22. Turner, S., Pryer, K. M., Miao, V. P. and Palmer, J. D. Investigating deep phylogenetic relationships among cyanobacteria and plastids by small subunit rRNA sequence analysis. J. Eukaryot. Microbiol. 46, 327-338. https://doi.org/10.1111/j.1550-7408.1999.tb04612.x (1999)

23. Nakano, S. et al. PCR detection of Bacillus and Staphylococcus in various foods. J. Food. Prot. 67, 1271-1277. https://doi.org/10.4315/0362-028x-67.6.1271 (2004)

24. Chao, A. et al. Rarefaction and extrapolation with Hill numbers: a framework for sampling and estimation in species diversity studies. Ecol. Monogr. 84, 45-67. https://doi.org/10.1890/13-0133.1 (2014)

25. R Core Team. R: a language and environment for statistical computing. Vienna (Austria): $R$ Foundation for Statistical Computing. Available from: https://www.r-project.org/ (2019)

26. Hsieh, T., Ma, K. \& Chao, A. iNEXT: an R package for rarefaction and extrapolation of species diversity (Hill numbers). Methods Ecol. Evol. 7, 1451-1456. https://doi.org/10.1111/2041-210X.12613 (2016)

27. Baumgartner, A., Kueffer, M., Simmen, A. \& Grand, M. Relatedness of Lactobacillus rhamnosus strains isolated from clinical specimens and such from food-stuffs, humans and technology. LWT 31, 489-494. https://doi.org/10.1006/fstl.1998.0395 (1998)

28. Chi, Z. et al. Bioproducts from Aureobasidium pullulans, a biotechnologically important yeast. Appl. Microbiol. Biotechnol. 82, 793-804. https://doi.org/10.1007/s00253-009-1882-2 (2009)

29. Agrawal, T. \& Kotasthane, A. S. Chitinolytic assay of indigenous Trichoderma isolates collected from different geographical locations of Chhattisgarh in Central India. SpringerPlus 1, 73. https://doi.org/10.1186/2193-1801-1-73 (2012)

30. Cattelan, A. J., Hartel, P. G. \& Fuhrmann, J. J. Screening for plant growth-promoting rhizobacteria to promote early soybean growth. Soil Sci. Soc. Am. J. 63, 1670-1680. https://doi.org/10.2136/sssaj1999.6361670x (1999)

31. Ramnath, L., Sithole, B. \& Govinden, R. Identification of lipolytic enzymes isolated from bacteria indigenous to Eucalyptus wood species for application in the pulping industry. Biotechnol. Rep. (Amst). 15, 114-124. https://doi.org/10.1016/j.btre.2017.07.004 (2017)

32. Chung, S. et al. Isolation and partial characterization of Bacillus subtilis ME488 for suppression of soilborne pathogens of cucumber and pepper. Appl. Microbiol. Biotechnol. 80, 115-123. https://doi.org/10.1007/s00253-008-1520-4 (2008) 
33. Athukorala, S. N., Fernando, W. D. \& Rashid, K. Y. Identification of antifungal antibiotics of Bacillus species isolated from different microhabitats using polymerase chain reaction and MALDI-TOF mass spectrometry. Can. J. Microbiol. 55, 1021-1032. https://doi.org/10.1139/w09-067 (2009)

34. Jain, D., Sunda, S. D., Sanadhya, S., Nath, D. J. \& Khandelwal, S. K. Molecular characterization and PCR-based screening of cry genes from Bacillus thuringiensis strains. 3 Biotech. 7, 4. https://doi.org/10.1007/s13205-016-0583-7 (2017)

35. Soares-da-Silva, J. et al. Molecular characterization of the gene profile of Bacillus thuringiensis Berliner isolated from Brazilian ecosystems and showing pathogenic activity against mosquito larvae of medical importance. Acta. Trop. 176:197-205. https://doi.org/10.1016/j.actatropica.2017.08.006 (2017)

36. Zhang, K., Baiocchi, T., Lu, D., Chang, D. Z. \& Dillman, A. R. Differentiating between scavengers and entomopathogenic nematodes: Which is Oscheius chongmingensis? J. Invertebr. Pathol. 167, 107245. https://doi.org/10.1016/j.jip.2019.107245 (2019)

37. Michereff, S. J., Silveira, N. S. S., Reis, A., Mariano, R. L. R. Epiphytic bacteria antagonistic to Curvularia leaf spot of yam. Microb. Ecol. 28, 101-110. https://doi.org/10.1007/BF00170250 (1994)

38. de Paiva, S. R., Figueiredo, M., Eyong, R., Aragão,. T V. \& Kaplan, M. A. C. Antimicrobial activity in vitro of plumbagin isolated from Plumbago species. Mem. Inst. Oswaldo. Cruz. 98, 959-961. https://doi.org/10.1590/s0074-02762003000700017 (2003)

39. Eyong,. K. O. et al. Newbouldiaquinone A: A naphthoquinone-anthraquinone ether coupled pigment, as a potential antimicrobial and antimalarial agent from Newbouldia laevis. Phytochemistry 67, 605609. https://doi.org/10.1016/j.phytochem.2005.12.019 (2006)

40. Saxena, A. K., Kumar, M., Chakdar, H., Anuroopa, N. \& Bagyaraj, D. J. Bacillus species in soil as a natural resource for plant health and nutrition. J. Appl. Microbiol. 128, 1583-1594. https://doi.org/10.1111/jam.14506 (2019)

41. de Andrade-Neto, V. F. et al. Antimalarial activity of phenazines from lapachol, beta-lapachone and its derivatives against Plasmodium falciparum in vitro and Plasmodium berghei in vivo. Bioorg. Med. Chem. Lett. 14, 1145-1149. https://doi.org/10.1016/j.bmcl.2003.12.069 (2004)

42. Maget-Dana, R., Thimon, L., Peypoux, F. \& Ptaka, M. Surfactin/iturin A interactions may explain the synergistic effect of surfactin on the biological properties of iturin A. Biochimie. 74, 1047-1051. https://doi.org/10.1016/0300-9084(92)90002-V (1992)

43. Fischer, D. et al. Disruption of membrane integrity by the Bacterium-derived antifungal jagaricin. Antimicrob. Agents. Chemother. 63, e00707-19. https://doi.org/10.1128/AAC.00707-19 (2019)

44. Murfin, K. E., Whooley, A. C., Klassen, J. L. and Goodrich-Blair, H. Comparison of Xenorhabdus bovienii bacterial strain genomes reveals diversity in symbiotic functions. BMC Genom. 16, 889. https://doi.org/10.1186/s12864-015-2000-8 (2015)

45. Fukruksa, C. et al. Isolation and identification of Xenorhabdus and Photorhabdus bacteria associated with entomopathogenic nematodes and their larvicidal activity against Aedes aegypti. Parasit. Vectors 10, 440. https://doi.org/10.1186/s13071-017-2383-2 (2017) 
46. Paredes, J. C., Herren, J. K., Schüpfer, F. \& Lemaitre, B. The role of lipid competition for endosymbiontmediated protection against parasitoid wasps in Drosophila. mBio 7, e01006-16.

https://doi.org/10.1128/mBio.01006-16 (2016)

47. Xie, J., Vilchez, I. \& Mateos, M. Spiroplasma bacteria enhance survival of Drosophila hydei attacked by the parasitic wasp Leptopilina heterotoma. PLoS One 5, e12149. https://doi.org/10.1371/journal.pone.0012149 (2010)

48. Brillard, J., Ribeiro, C., Boemare, N., Brehélin, M. \& Givaudan, A. Two distinct hemolytic activities in Xenorhabdus nematophila are active against immunocompetent insect cells. Appl. Environ. Microbiol. 67, 2515-2525. https://doi.org/10.1128/AEM.67.6.2515-2525.2001 (2001)

49. Gupta, R., Beg, Q. \& Lorenz, P. Bacterial alkaline proteases: molecular approaches and industrial applications. Appl. Microbiol. Biotechnol. 59, 15-32. https://doi.org/10.1007/s00253-002-0975-y (2002)

50. Merzendorfer, H. Insect-derived chitinases. Adv. Biochem. Eng. Biotechnol. 136, 19-50. https://doi.org/10.1007/10_2013_207 (2013)

51. Bhunia, B., Basak, B. \& Dey, A. A review on production of serine alkaline protease by Bacillus spp. J. Biochem. Technol. 3, 448-457. https://doi.org/10.1016/S0032-9592(00)00275-2 (2012)

52. Payne, J. W. \& Smith, M. W. Peptide transport by micro-organisms. Adv. Microb. Physiol. 36, 1-80. https://doi.org/10.1016/S0065-2911(08)60176-9 (1994)

53. Bidochka, M. J. \& Khachatourians, G. G. Growth of the entomopathogenic fungus Beauveria bassiana on cuticular components from the migratory grasshopper, Melanoplus sanguinipes. J. Invertebr. Pathol. 59, 165-173. https://doi.org/10.1016/0022-2011(92)90028-3 (1992)

54. Leger, R. S., Joshi, L., Bidochka, M. J., Roberts, D. W. Construction of an improved mycoinsecticide overexpressing a toxic protease. Proc. Natl. Acad. Sci. USA 93, 6349-6354. https://doi.org/10.1073\%2Fpnas.93.13.6349 (1996)

55. Merzendorfer, H. \& Zimoch, L. Chitin metabolism in insects: structure, function and regulation of chitin synthases and chitinases. J. Exp. Biol. 206, 4393-4412. https://doi.org/10.1242/jeb.00709 (2003)

56. Kelkenberg, M., Odman-Naresh, J., Muthukrishnan, S. \& Merzendorfer, H. Chitin is a necessary component to maintain the barrier function of the peritrophic matrix in the insect midgut. Insect Biochem. Mol. Biol. 56, 21-28. https://doi.org/10.1016/j.ibmb.2014.11.005 (2015)

57. Sampson, M. N. and Gooday, G. W. Involvement of chitinases of Bacillus thuringiensis during pathogenesis in insects. Microbiology 144(Pt8), 2189-2194. https://doi.org/10.1099/00221287-1448-2189 (1998)

58. Han, K. I. et al. Characterization of chitinase-producing Serratia and Bacillus strains isolated from insects. Entomol. Res. 44, 109-120. https://doi.org/10.1111/1748-5967.12056 (2014)

59. Brzezinska, M. S., Jankiewicz, U., Burkowska, A. \& Walczak, M. Chitinolytic microorganisms and their possible application in environmental protection. Curr. Microbiol. 68, 71-81. https://doi.org/10.1007/s00284-013-0440-4 (2014) 
60. Wang, C. \& Leger, R. J. S. Developmental and transcriptional responses to host and nonhost cuticles by the specific locust pathogen Metarhizium anisopliae var. acridum. Eukaryot, Cell 4, 937-947. https://doi.org/10.1128\%2FEC.4.5.937-947.2005 (2005)

61. Kobmoo, N. et al. A genome scan of diversifying selection in Ophiocordyceps zombie-ant fungi suggests a role for enterotoxins in co-evolution and host specificity. Mol. Ecol. 27, 3582-3598. https://doi.org/10.1111/mec.14813 (2018)

62. Bengtsson, G. Interactions between fungi, bacteria and beech leaves in a stream microcosm. Oecologia 89, 542-549. https://doi.org/10.1007/BF00317161 (1992)

63. Kamenek, L. K., Kamenek, D. V., Terpilowski, M. A. \& Gouli, V. V. Antifungal action of Bacillus thuringiensis delta-endotoxin against pathogenic fungi related to Phytophthora and Fusarium. J. Agric. Sci. Technol. 8, 191-203. http://www.ijat-aatsea.com/Past_v8_n1.html (2012)

64. Mohammed, S. H., Saedy, M., Enan, M. R., Ibrahim, E. \& Moustafa, A. Biocontrol efficiency of Bacillus thuringiensis toxins against root-knot nematode, Meloidogyne incognita. J. Cell Mol. Biol. 7, 57-66. (2008)

\section{Figures}




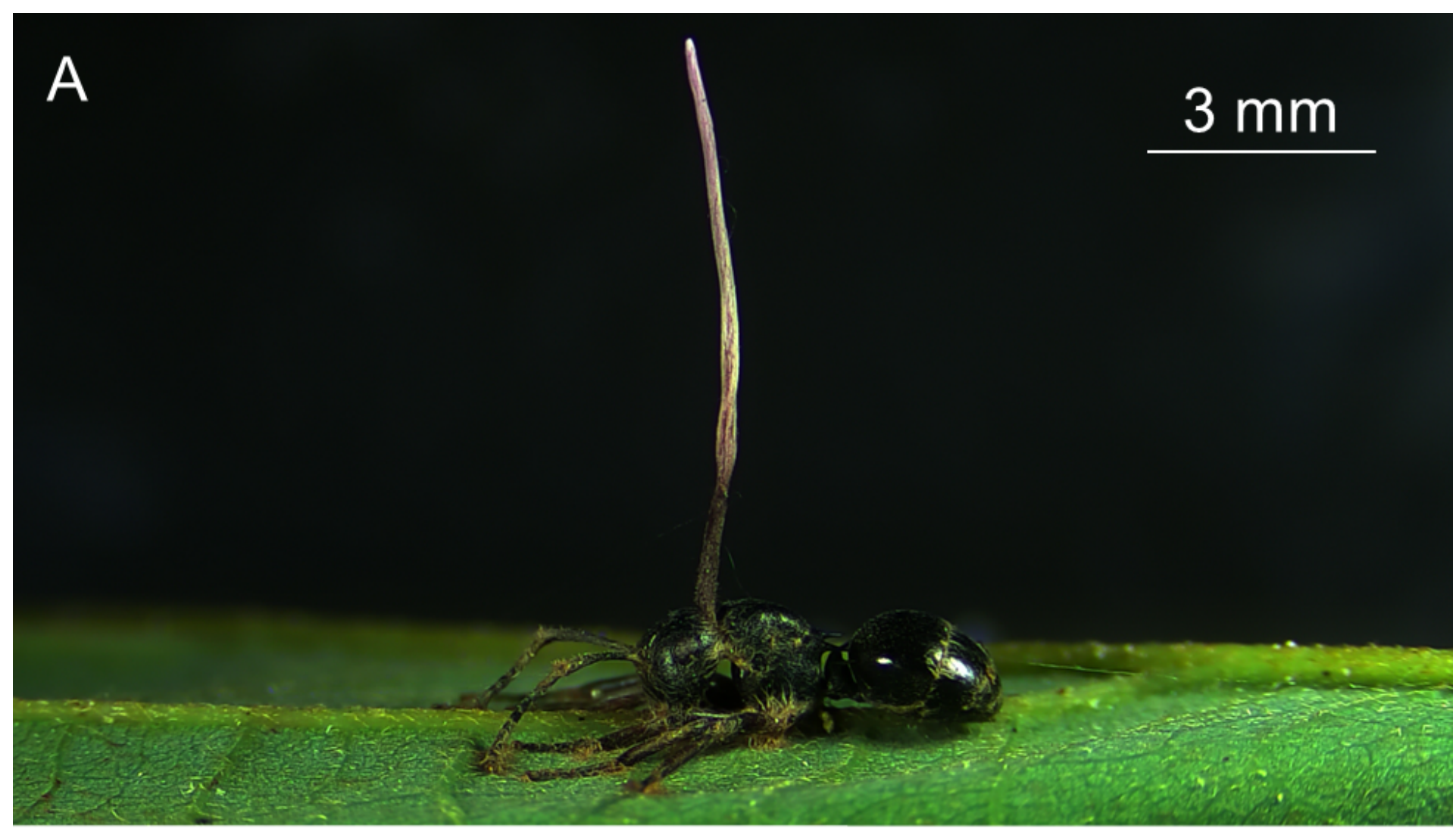

B

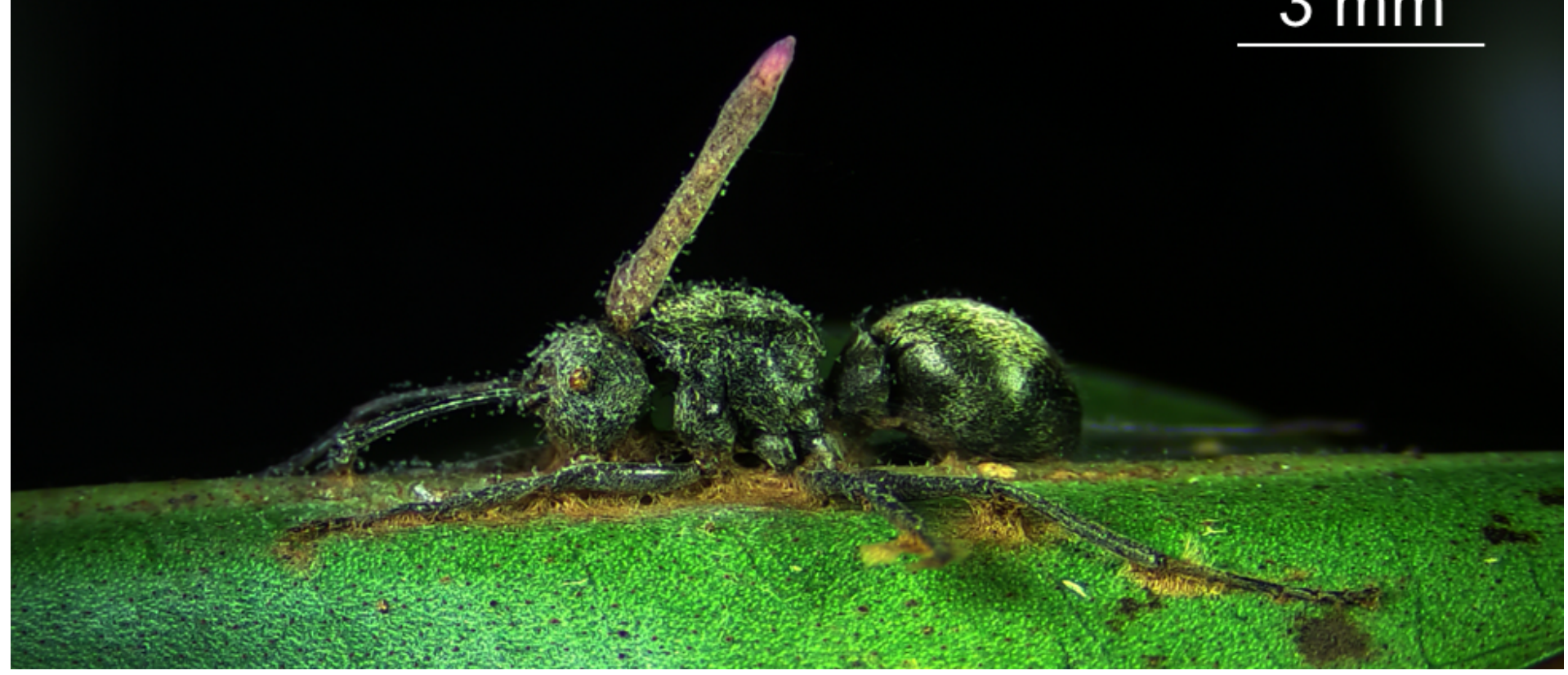

Figure 1

Ophiocordyceps unilateralis sensu lato-infected (a) Polyrhachis moesta and (b) P. wolfi, with the stroma growing from the ant cadaver. 

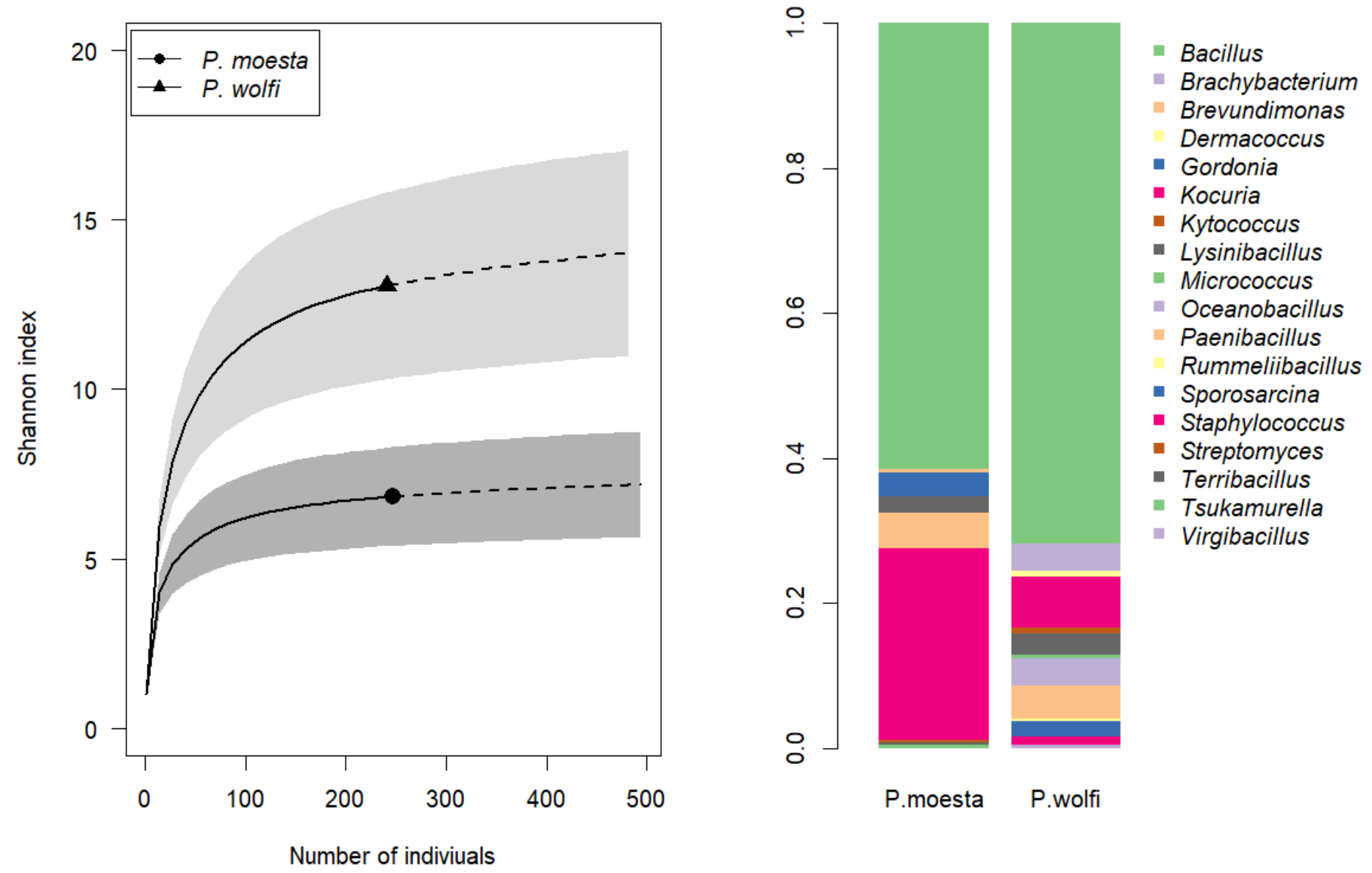

Figure 2

Species diversity and genus abundance of bacteria isolated from ant cadavers infected by Ophiocordyceps unilateralis sensu lato. 

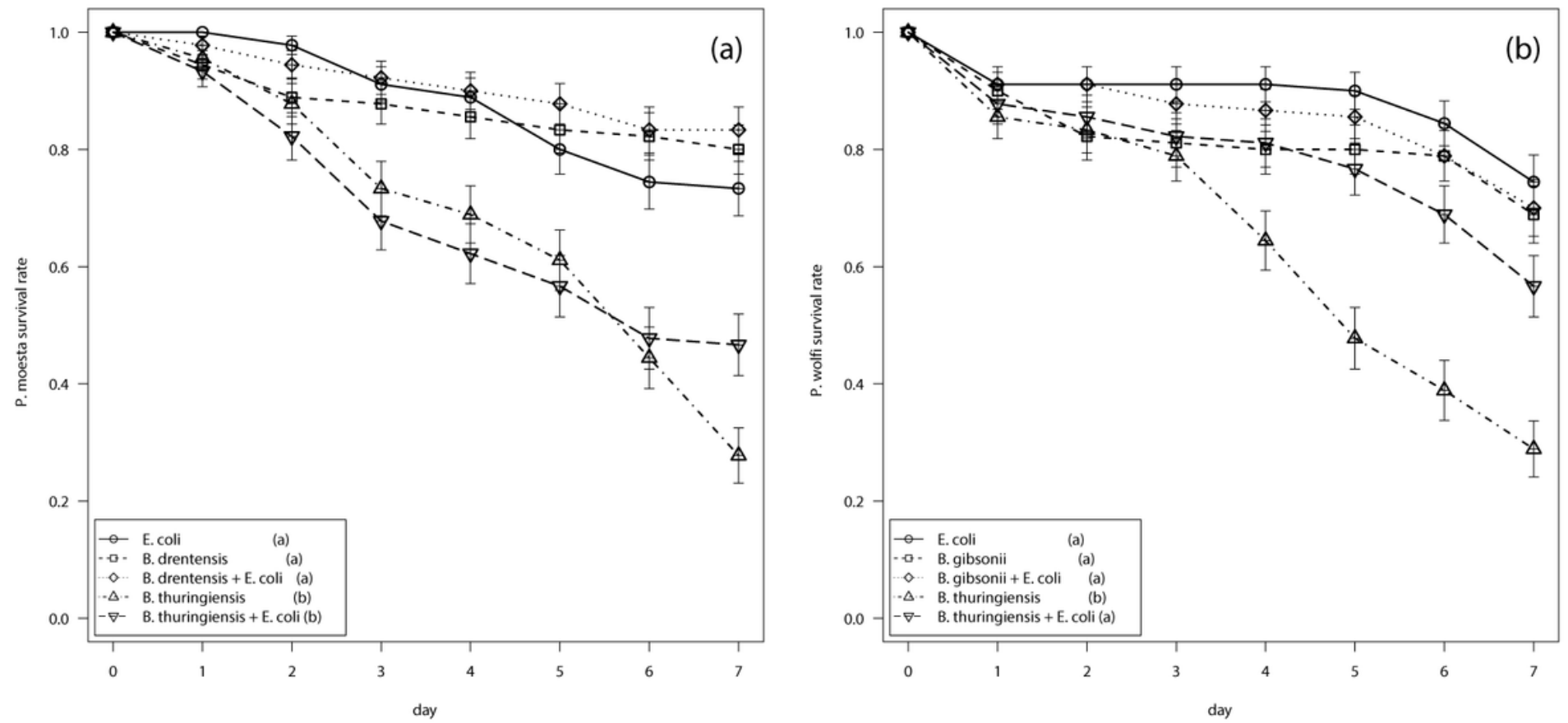

\section{Figure 3}

Daily cumulative mortality rate (\% $\pm \mathrm{SE})$ of the nematode, Caenorhabditis elegans, co-cultured with hemolytic and non-hemolytic bacteria isolated from ant cadavers of (a) the principal host, Polyrhachis moesta, and (b) the alternative host, P. wolfi, of Ophiocordyceps unilateralis sensu lato.
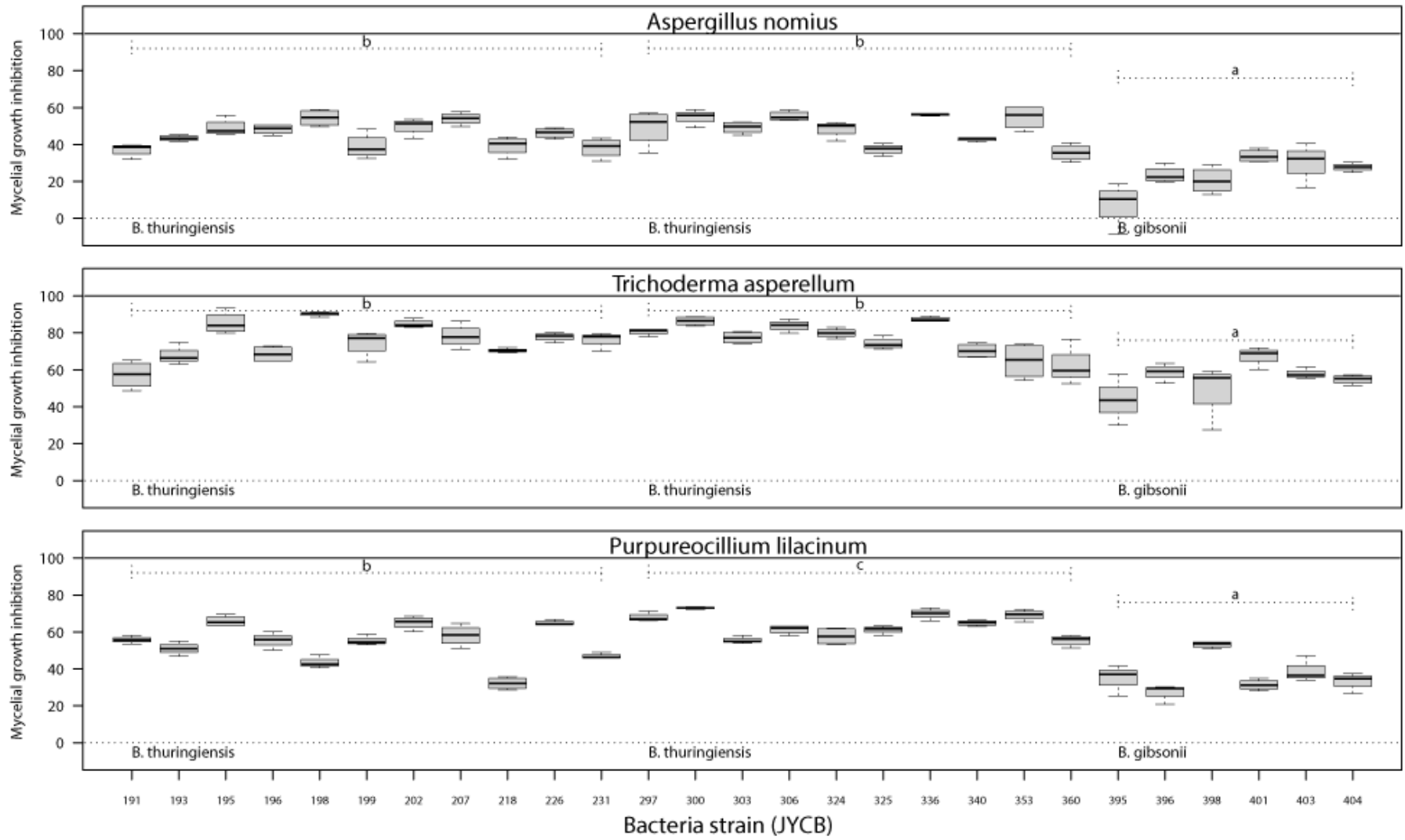

Page $21 / 23$ 
Figure 4

Mycelial growth inhibition (MGI) value of three entomopathogenic fungi under the effects of three predominant Bacillus strains isolated from ant cadavers infected by Ophiocordyceps unilateralis sensu lato. Letters indicate significant pairwise differences among the Bacillus species (Tukey's all-pair comparisons using the beta regression model, $p<0.05$ ).
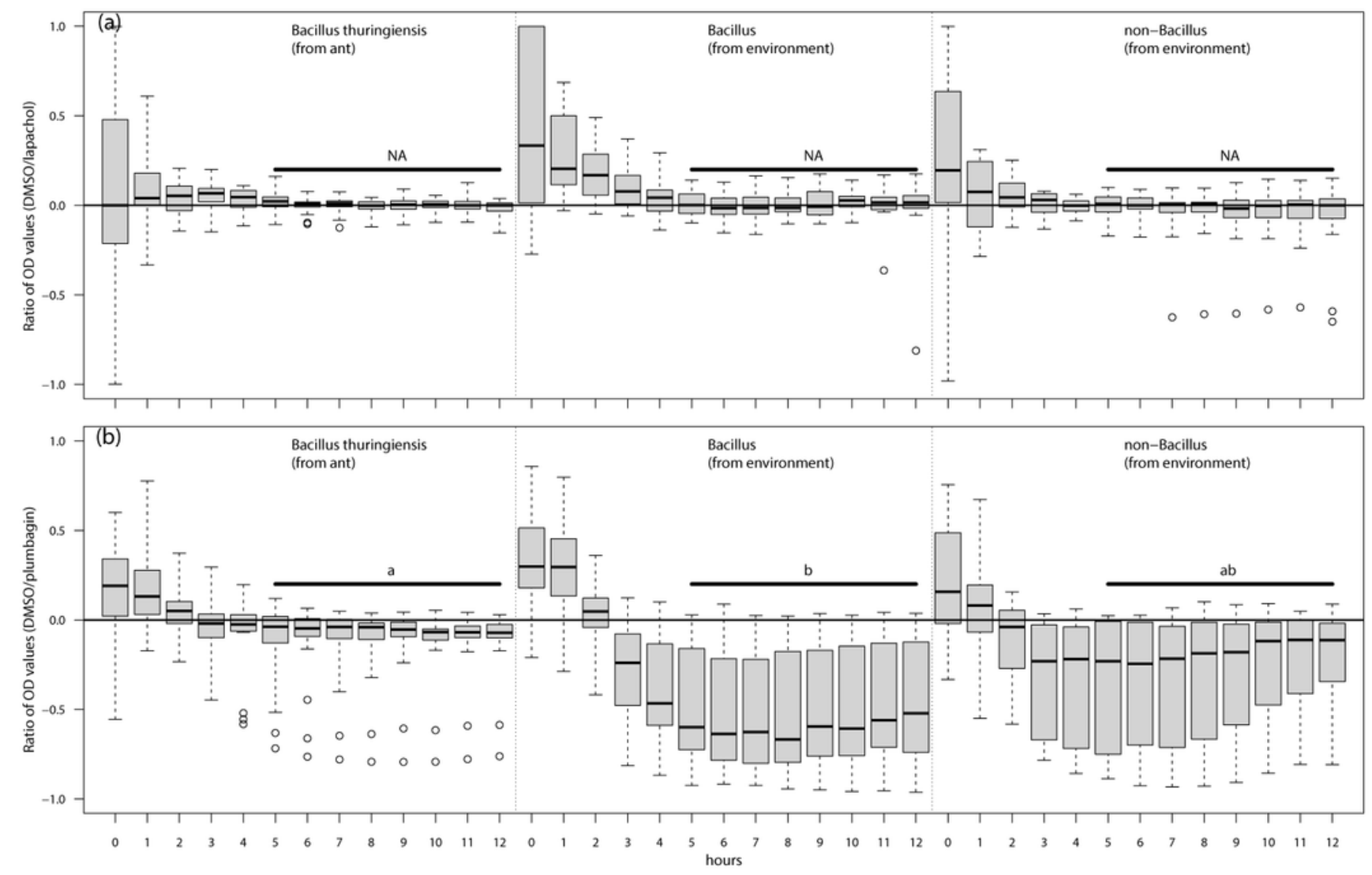

\section{Figure 5}

The resistance index of bacterial growth in the presence of two naphthoquinones, lapachol (a) and plumbagin (b). Letters indicate significant pairwise differences between Bacillus thuringiensis isolated from ant cadavers of Polyrhachis moesta, Bacillus isolates from the environment, and non-Bacillus isolates from the environment (Tukey's all-pair comparisons using the linear mixed model, $p<0.05$ ).

\section{Supplementary Files}

This is a list of supplementary files associated with this preprint. Click to download.

- SupplementaryFigure1.tif 
- SupplementaryFigure2.tif

- SupplementaryFigure3.tif

- Supplementaryfile1.csv

- Table20210603.docx 